\title{
РЕАКЦИЯ РЕГИОСПЕЦИФИЧНОГО $S$-АМИНОАЛКИЛИРОВАНИЯ ПРОИЗВОДНЫХ 5-АЛКИЛ-6-ГИДРОКСИ-2-ТИОУРАЦИЛА В НАПРАВЛЕННОМ КОНСТРУИРОВАНИИ СТРУКТУРНЫХ АНАЛОГОВ ИЗОТИОБАРБАМИНА
}

\author{
Д.С. Шейкин', И.А. Новаков', М.Б. Навроцкий', Л.Л. Брунилина', \\ Н.А. Салыкин', Л.А. Саблина ${ }^{2}$, М.Ю. Воронцов² \\ ${ }^{1}$ ФБООУ ВО Волгоградский государственный технический университет, \\ 400005, Российская Федерация,Волгоград, пр. имени Ленина, 28. \\ ${ }^{2}$ ФГБОУ ВО Волгоградский государственный медицинский университет Министерства \\ здравоохранения Российской Федерации, Российская Федерация, \\ 400131 Волгоград, пл. Павших Борцов, 1.
}

DOI: 10.19163/MedChemRussia2021-2021-242

E-mail:d.sheikin@yandex.ru

С целью направленного конструирования новых структурных аналогов Изотиобарбамина, обладающихактопротекторными и антигипоксическими свойствами, была изучена реакция S-аминоалкилирования производных 5-алкил-6-гидрокси-2-тиоурацила, а также подобраны условия, в которых эта реакция проходит региоспецифически. Достичь этого результата удалось с использованием безводного $i$ - $\mathrm{PrOH}$ в качестве растворителя и предварительного приготовления растворов свободных $N, N$-диалкил- $N-(2$-хлорэтил)аминов обработкой их гидрохлоридов раствором $i$-PrONa в $i$-PrOH. Это позволило на ранней стадии отделить $\mathrm{NaCl}$, практически нерастворимый в $i-\mathrm{PrOH}$, и обеспечить протекание алкилирования в гомофазе[1,2]:
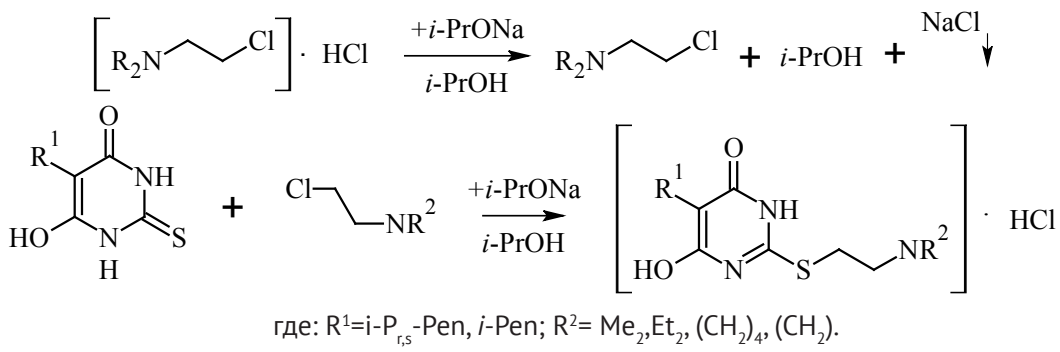

Структура и чистота полученных соединений доказаны с использованием современных физико-химических методов анализа. Целевые соединения были подвергнуты исследованиям в тестах in vivo. Установлено, что они проявляют актопротекторные, ноотропныеи анксиолитические свойства.

\section{Литература}

[1] Пат. 2744470 РФ, МПК С07D239/66. Способ получения Изотиобарбамина. И. А. Новаков, Л. Л. Брунилина, П. П. Дешевов., М. Б. Навроцкий, Д. С. Шейкин. - ВолгГТУ. - 2018.

[2] И. А. Новаков, Д. С. Шейкин, В. В. Чапуркин, М. Б. Навроцкий, Б. Д. Кореньков, И. А. Кириллов, П. П. Дешевов, О. В. Вострикова, Л. Л. Брунулина. Региоспецифичное S-аминоалкилирование 5-замещенных производных 6-гидрокси-2-тиоурацила в синтезе структурных аналогов изотиобарбамина. // Известия Академии Наук Серия Химическая. - 2021. - № 5. - С. 943-948. 